\title{
Cross-Level Cultural Congruence: Implications For Managing Diversity In Multinational Corporations
}

Jennifer Palthe, Western Michigan University, USA

\begin{abstract}
Few models view culture as a multi-level construct and limited diversity management theories capture the significance of the configuration of individual, organizational, and national culture differences on employee and organizational outcomes.

This paper seeks to bridge this gap by presenting a conceptual model that suggests that the interplay between this triad of cultural entities (individual, organizational, and national) influences the degree of cultural congruence that ultimately affects individual and organizational outcomes. Figures that serve as explanations of these cultural configurations are presented and implications for diversity management research and practice are offered.
\end{abstract}

Keywords: Cross-Cultural Diversity Management; Multi-Level Cultural Congruence; Organization Culture

\section{INTRODUCTION}

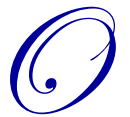

rganizations, like individuals, are as diverse and varied as the nations of the world within which they are embedded. The impact of this cultural diversity at the national and organizational levels has been of interest to numerous behavioral scientists and organizational theorists, particularly over the last three decades (Adler \& Bartholomew, 1992; Hofstede, 1991; House, Wright, \& Aditya, 1997; House, Hanges, RuizQuintanilla, Dorfman, Javidan, Dickson, Gupta, \& GLOBE, 1999; Stahl, Maznevski, Voigt, \& Jonsen, 2010). Attention, however, has been focused primarily on cultural comparisons rather than cultural interactions and their impact on organizational practices (Gelfand, Erez, \& Aycan, 2007). Moreover, cross-cultural diversity research has primarily paid attention to the impact of individual demographic differences on job outcomes (Tsui \& Eagan, 1995) and few studies have examined culture at multiple levels or used a multi-level framework for understanding the reciprocal relationship between levels of culture (Erez \& Gati, 2004). While purposeful change in multinational corporations is causing cultural segregation to be replaced by cultural integration and homogenization with pluralism (Tsui, 2007), organizational theorists have failed to fully come to grips with cross-level cultural configurations that influence organizational outcomes (Klein \& Kozlowski, 2000).

The challenge of both measuring and managing diverse cultural factors within the same national culture cannot be underestimated. However, the task of deciphering both national and organizational differences of firms engaging in joint ventures across national boundaries is even more perplexing. An understanding of the interaction between individual values, organizational culture, and national cultural variables and their impact on organizational outcomes is critical to furthering our knowledge and enhancing our ability to manage diversity more effectively.

This paper examines the literature on cross-cultural diversity, organizational culture, and cross-cultural management. The interplay between diverse individual values, organizational cultures, and national cultures, and their combined influence on individual and organizational outcomes is explored. The variables are defined and dimensions along which they vary are highlighted. A model is presented and its implications for cross-cultural diversity management research and practice are outlined. 


\section{DEFINITIONS OF KEY CONSTRUCTS}

Cross-cultural management is defined as the study of the behavior of people in organizations located in cultures and nations around the world (Adler, 1983). It examines the varying forms of organizational behaviors in different nations and cultures and, most importantly, as Adler (1983) argues, the interaction between people of different countries working in the same organization, strategic alliance, or venture. Cultural diversity is defined as the representation, in one social system, of people with distinctly different group affiliations of cultural significance (Cox, 1993). Similarly, diversity management involves planning and implementing organizational systems and practices to manage people so that the potential advantages of diversity are maximized while its potential disadvantages are minimized (Cox, 1993). Therefore, cross-cultural diversity management could be viewed as the management of organizational behavior and systems, such that the advantages of cross-cultural diversity are optimized while the potential disadvantages are attenuated.

Cross-cultural competence is the ability to work effectively with people from different cultural backgrounds (Johnson, Lenartowicz, \& Apud, 2006). Organization culture, as distinct from national culture, is viewed by most scholars on the subject as a pattern of shared basic assumptions that the group learned as it solved its problems of external adaptation and internal integration (Schein, 1985). Consistent with this, others contend that culture is a way of life of a group of people - a configuration of all of the more or less stereotyped patterns of learned behavior, which are handed down from generation to generation via language and imitation (Adler, Doktor, $\&$ Redding, 1986). Denison (1996) views culture as an evolved context within which a situation or climate may be embedded. He defines organizational culture as the underlying values, beliefs, and principles that serve as a foundation for the organization's management system, as well as the set of management practices and behaviors that both exemplify and reinforce those principles. Cox (1993) contends that culture is part of a network of embedded cultures similar to the view held by Alderfer (1982) who describes groups as being embedded within larger cultural groups. Others view culture as the set of important assumptions (often unstated) that members of a community share in common.

Closer inspection of these definitions exemplifies the underlying significance of values in explaining every level of culture, whether national, organizational, or individual. Cultural congruence refers to the degree of alignment between two or more cultural configurations and is measured by degrees of overlap and distance between them (Cox, 1993). Peters and Waterman (1982) contend that efficient cultures are a source of sustainable competitive advantage. Others have argued that cultural compatibility or "fit" is a primary determinant of organizational success (Adler, 1983; Hakanson, 1995).

\section{A CONCEPTUAL MODEL OF CROSS-LEVEL CULTURAL CONGRUENCE}

Model I suggests that individual and organizational outcomes are mediated by the degree to which individual values, organizational culture, and national culture are compatible. Although cultural variations at each of these levels have been recognized as impacting individual and organizational outcomes, empirical studies examining the interaction between these three levels have not been forthcoming. Understanding the variations in and amongst national and organizational cultures becomes important when trying to explain why some individuals perform better and with greater ease in organizational cultures and national environments apparently diverse from their own. It may also explain why some individuals operating in an organizational culture that they are comfortable with, but in a nation diverse from its own, underperform and withdraw.

In order to examine the major dimensions of which Model I is comprised and to further develop this analysis, a brief overview of each of the variables under consideration will follow. 


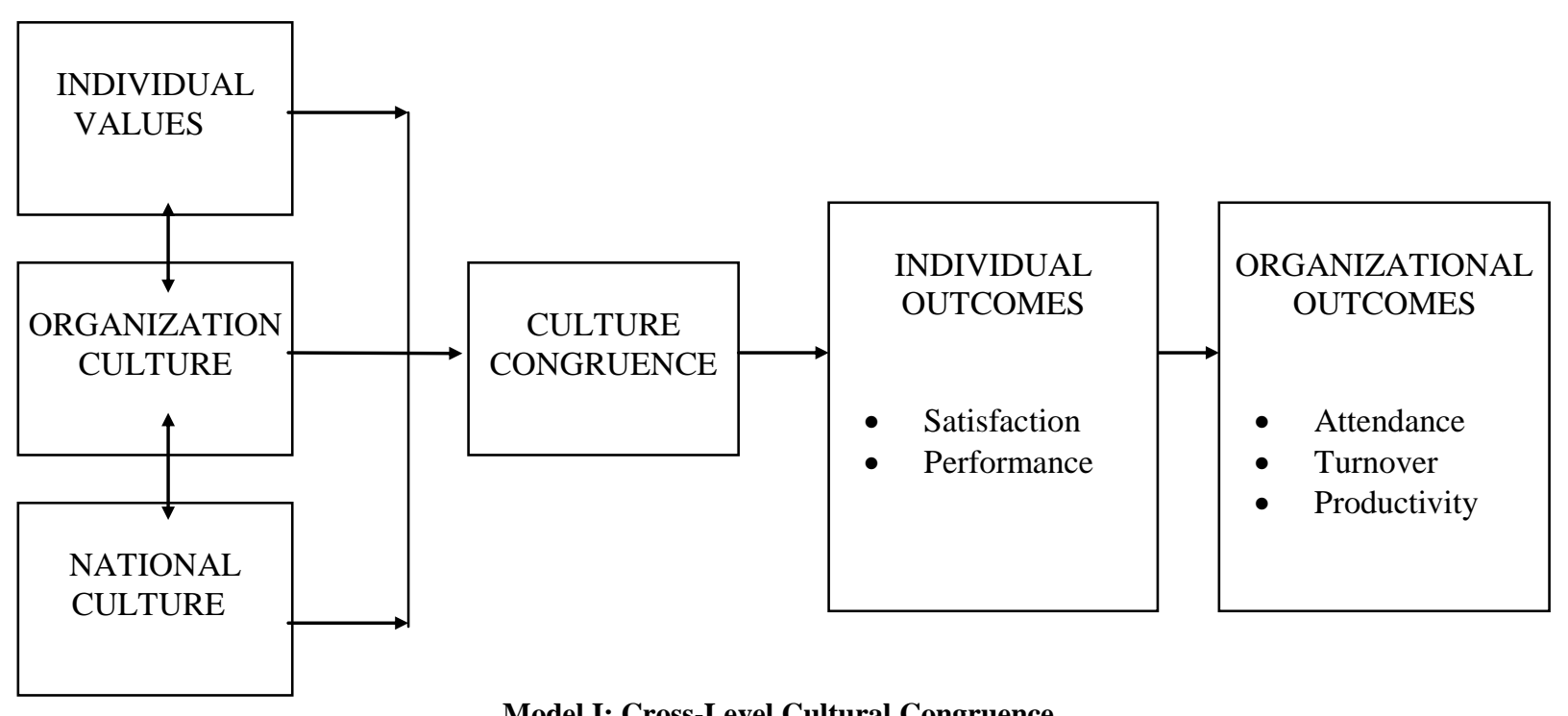

Model I: Cross-Level Cultural Congruence

\section{Individual Value Dimensions}

Common across all levels of social analysis is the concept of values. They are one of the most fundamental and enduring characteristics applicable to both individuals and organizations (Hofstede, 1980) and hence provide a powerful means of understanding interrelationships between them. Individual values are defined as generalized and relatively enduring beliefs about the personal and social desirability of modes of conduct (Kabanoff, Waldersee, \& Cohen, 1995) and a broad tendency to prefer certain states of affairs over others (Hofstede, 1980). Values involve patterned (rank ordered) principles (Kluckhohn \& Strodbeck, 1961) that guide actions and judgments (Chatman, 1991).

Miliken \& Martins (1996) draw our attention to just how few organizational studies there are that actually focus on how diversity, with respect to cultural values, affect outcomes for individuals and organizations. Erez \& Early (1993) distinguish between three ways in which individuals may differ with respect to their values - selfenhancement, self-efficacy, and self-consistency.

Both cognitive processes and opportunities in the environment affect individual tendencies toward selfenhancement. Individuals tend to process self-congruent stimuli more efficiently, judging others on dimensions that are personally relevant. Enhancement for the collectivist self may be closely related to individuals contributing to the success of the team, for example. Conversely, enhancement for the individualist would, according to this dimension, be positively related to individual achievement. Some individuals tend to avoid situations and tasks that they do not believe they are capable of handling. To protect positive self-efficacy, individuals tend to attribute failure to situational factors. Other individuals, however, may have high internal loci of control and attribute failure or success to personal attributes (Cox, 1993). Self-efficacy, although developed with respect to the individual, could also be extended to the group, organizational, and even national level in the form of collective efficacy (Erez \& Early, 1993). Arguably, certain organizational cultures and nations may exhibit greater collective efficacy than others. Self-consistency, unlike self-enhancement and self-efficacy, has received very little empirical attention. Selfconsistency is said to direct individuals to behave in accordance with the values and norms implied by the identities to which they are committed (Erez \& Early, 1993). Self-consistency provides a sense of continuity and stability in individuals as it involves the construction of world views consistent with an individual's self image. For example, employees may attribute an inability to accomplish a task or operate a particular machine to an environmental factor such as noise. Self-consistency may also affect the degree of acceptance individuals may display of managerial techniques. Those consistent with cultural norms are more likely to be accepted than others (Erez \& Early, 1993).

Degrees of self-enhancement, self-efficacy, and self-consistency differ across cultures as do meanings of self-worth and criteria for self-evaluation. Criteria used by the private self are supported by individualistic values. 
The public self is viewed as an extension of the private or collective self, depending on whether collectivistic or individualistic values are upheld (Triandis, 1994). In individualistic cultures, generalized others are assumed to reinforce autonomy and independence, whereas collectivistic cultures promote subjection of the private goals to collective goals (Erez \& Early, 1993). Individualistic values are synonymous with Western cultures where the self is less connected and more differentiated from the social context, thereby more independent. In contrast, Eastern cultures are characterized by more collectivism, group orientation, and interdependence (Hofstede, 1980).

The typology of the three dimensions of self (enhancement, efficacy, and consistency) highlighted by Erez \& Early (1993), as well as the classification of private and collective selves and independent or interdependent selves, forms a useful array of dimensions along which individuals could be measured cross-culturally. Moreover, they represent a starting point for the development of potential measures whereby individual behavior across cultures can be predicted. Using these dimensions, the potential link between diverse individual values and satisfaction at work begins to unfold. Schein (1985) contends that interactions between individuals can differ along five dimensions; namely, 1) self or collective-oriented, 2) ascription or achievement-oriented, 3) universalistic or particularistic, 4) diffuse or specific, and 5) emotionally charged or emotionally neutral. These dimensions, like Erez \& Early's (1993), are potentially valuable frameworks along which individuals' values and assumptions (and hence predictable behavior) can be evaluated. The challenge, however, is to translate these dimensions into reliable measures and to integrate them with organizational and national culture measures such that consistent comparisons across levels can be achieved.

\section{Dimensions of Organizational Culture}

Culture includes systems of values that form one of the fundamental components of national culture (Hofstede, 1980) and organizational culture (Schein, 1985). Organizational culture is defined as the underlying values, beliefs, and principles that serve as a foundation for an organization's management system, together with a set of management practices and behaviors that both exemplify and reinforce those principles (Denison, 1990). Organizational values are group products (Schein, 1985) that provide a justification for the appropriate member behavior and for the practices of the system (Chatman, 1991). Strong organizational values are intensely held and widely shared (Deal \& Kennedy, 1982). There is clear empirical evidence that there are significant differences among national cultures in individualistic and collectivistic values and in power distance (the psychological distance between different levels in the organizational hierarchy) (Hofstede, 1980). In an attempt to operationally define and measure organizational culture, Hofstede et al. (1990) identified six dimensions or "perceived common practices" along which organizations can differ: 1) process orientation, 2) employee orientation, 3) professional orientation, 4) tight control, 5) normative orientation, and 6) pragmatic orientation.

They argued that organizational cultures vary with respect to how much value they attach to the attainment of goals, compared with the importance they attach to the compliance with rules and procedures designed to support those goals. Having a process-oriented organizational culture suggests that a firm tends to focus on means rather than ends. Examples of different organizational cultures within this dimension could be multinational parent companies attaching greater importance to the production processes while their acquired subsidiaries pay more attention to the production outcomes. Organizations also differ in terms of the attention they pay to their employees' well-being. Some organizational cultures are more task-oriented and others are more employee-oriented. Pronounced differences in this dimension parallel those in national cultures characterized by low power distance. Another dimension along which organizations may differ is professional orientation. This dimension differentiates between organizations that have strong professional cultures with an emphasis on training and the job as opposed to organizations where commitment to the company is emphasized. Yet another dimension includes tight control. Organizations that are characterized by tight control have more and closer supervision of subordinates and more elaborate systems of cost and quality control, for example. High levels of documentation can be indicative of tight control (Hakanson, 1995). Pragmatic organizational units tend to be market driven and their activities more oriented toward customer satisfaction. Conversely, normative units tend to be more removed from customers and market activities (Hakanson, 1995). These dimensions provide a starting point for measuring organizational culture in diverse contexts. Such contexts may include a joint venture between two organizations with diverse organizational cultures in an international setting. 


\section{Dimensions of National Culture}

Of the few studies of national culture that have been conducted, dimensions of importance have centered primarily around the notion of individualism and collectivism, self versus group, and task versus relational orientation. In a seminal piece by Kluckhohn \& Strodbeck (1961), they presented five dimensions of significance with which to assess national culture differences and their effects on managerial behavior in diverse organizational contexts. These dimensions include 1) relationship to self, 2) relationship to others, 3) relationship to external environment, 4) activity, and 5) time. Cox's (1993) analogy of space and time variations is also potentially useful and concurs with Kluckhohn and Strodbeck's (1961). Another more recent set of dimensions that have been proposed by Schwartz (1994) includes: 1) self direction, 2) universalism, 3) benevolence, 4) tradition, 5) conformity, 6) security, 7) power, 8) achievement, 9) hedonism, and 10) stimulation.

Probably the most highly referenced typology of national cultures, however, is that presented by Hofstede (1980) in his study of 160,000 employees working in 40 different countries for a U.S. multinational. He highlighted four dimensions in which styles of work differ across nations: 1) power distance, 2) individualism/collectivism, 3) uncertainty avoidance, and 4) masculinity/femininity. Brief descriptions of each of these dimensions will follow. Power distance is a dimension that attempts to explain differences in the perception of legitimate authority across cultures. Hofstede (1980) found power distance in England to be smaller than in France, with English managers perceiving authority to be vested in the individual. He found the French to view authority as vested in the role. Arguably, this relates to the organizational culture typology highlighted by Hofstede et al. (1990) around the notion of person versus task-oriented organizations.

A comparison between South American and North American cultures revealed that power distance in South America is higher than in North America (Erez \& Early, 1993). The implication of this for organizations is that South Americans, for example, have greater difficulty delegating authority than their North American counterparts (Hofstede, 1980). When considering the dimension pertaining to individualism and collectivism, it is important to note that Japan and Korea are renowned for their collectivistic values, while the U.S. is known for its individualistic culture. This has implications for communication styles, decision-making, and goal setting at work. Meetings in Japan, for example, are longer and more frequent than in Western cultures and decision-making is more timeconsuming. Americans, on the other hand, invite confrontation and are quicker decision-makers (Erez \& Early, 1993).

A high level of uncertainty avoidance lends itself to explicit, unambiguous communication styles. Israelis, for example, are driven by uncertainty avoidance, so too are the Japanese, according to Hofstede (1980). However, the juxtaposition of other cultural variables, such as power distance on this dimension, gives rise to other differences evident between the two cultures. The masculinity/femininity dimension refers to the dominant sex roles in societies. Japan comes out at the top of the list of countries high on masculinity. Others include Germany, Switzerland, Austria, and Mexico. Feminine cultures, on the other hand, include France, Spain, Portugal, and Chile. Feminine cultures are characterized as more emotionally or relationally-oriented with high nurturance interests, whereas masculine cultures have stronger "social egos," with high assertiveness interests (Hofstede, 1980).

\section{Cultural Congruence}

Thus far, this paper has highlighted some key dimensions along which individual values, organizational cultures, and national cultures can be evaluated. The question that remains unanswered, however, is how the interaction of all three of these levels together impact individual and organizational effectiveness. What level of value congruence is necessary for organizational effectiveness? Are individuals who are more group-orientated, working for an organization that is more individualistic in a nation that espouses competitive and self-oriented behavior likely to withdraw from organizational life and underperform? Would the same individual perhaps continue performing effectively but at the expense of being dissatisfied and unhappy? Using the same analogy, would a self-oriented individual working for an individualistic company in a nation that fosters collectivism be dissatisfied and therefore underperform in response to value incongruence due to national culture factors?

Person-organization interactions have not been examined as thoroughly as person-vocation interactions (Chatman, 1991) and previous research has primarily concentrated on the effect of value incongruity on job 
outcomes. Results of studies have generally shown that the value incongruity between supervisors and subordinates has a small negative correlation with job satisfaction and organizational effectiveness (Gelfand et al., 1996). Although interactional research in organizations has been fruitful, some have called for it to be more comprehensive (Chatman, 1989; Ostroff \& Rothausen, 1997). Very little is known about the interaction of value congruity using a triad of nation, organizational culture, and individual value differences. For example, different values held by individuals in New Zealand and Taiwan could affect the interpretation of identical situations as these cultures differ on the values of individualism and collectivism. This, in turn, may occur within an organization that espouses collectivism. The individual whose values concur with the organizations and the nation, as a whole, is likely to have an easier time performing as required and, hence, is likely to more readily obtain rewards and recognition as a consequence. As values influence individuals' choice of behavior and as behaviors most consistent with or in alignment with an individual's values will give rise to greatest job satisfaction, value-fit strategies must naturally be of concern to global corporations (Schwartz, 1990; Early 1994; Gelfand et al., 1996). Table I serves to offer potential linkages between individual, organizational, and national culture dimensions.

Table I: Linkages between Individual, Organizational, and National Culture Dimensions

\begin{tabular}{|l|l|l|l|}
\hline & \multicolumn{1}{|c|}{ Individual } & \multicolumn{1}{c|}{ Organizational } & \multicolumn{1}{|c|}{ National } \\
\hline Individual/Group & $\begin{array}{l}\text { Self efficacy or collective efficacy } \\
\text { (Erez \& Early, 1993) } \\
\text { Self direction (Schwartz, 1990) } \\
\text { Self versus group (Early, 1994) } \\
\text { Individualism versus collectivism } \\
\text { (Triandis et al., 1994) }\end{array}$ & $\begin{array}{l}\text { Employee orientation } \\
\text { (Hofstede et al., 1990) }\end{array}$ & $\begin{array}{l}\text { Individualism versus } \\
\text { collectivism (Hofstede, 1980; } \\
\text { Kluckhohn \& Strodbeck, 1961; } \\
\text { Triandis et al., 1994) }\end{array}$ \\
\hline Competition/Cooperation & $\begin{array}{l}\text { Self enhancement versus group } \\
\text { enhancement (Erez \& Early, 1993) }\end{array}$ & $\begin{array}{l}\text { Process orientation } \\
\text { (Hofstede et al., 1990) } \\
\text { Tight control (Hofstede } \\
\text { et al., 1990) }\end{array}$ & $\begin{array}{l}\text { Achievement versus affiliation } \\
\text { (Schwartz, 1994) } \\
\text { Masculine or feminine cultures } \\
\text { (Hofstede, 1980) }\end{array}$ \\
\hline Power & $\begin{array}{l}\text { Self Consistency (Erez \& Early, } \\
\text { 1993) }\end{array}$ & $\begin{array}{l}\text { Power (Schwartz, 1990) } \\
\text { et al., 1990) } \\
\text { Power distance (Hofstede, }\end{array}$ \\
\hline Communication & $\begin{array}{l}\text { Confrontational versus consensus } \\
\text { oriented (Cox, 1993) }\end{array}$ & $\begin{array}{l}\text { Process orientation } \\
\text { (Hofstede et al., 1990) }\end{array}$ & $\begin{array}{l}\text { Uncertainty avoidance } \\
\text { (Hofstede, 1980) }\end{array}$ \\
\hline
\end{tabular}

When the examination of value differences is extended to national, organizational, or individual value fit, new questions arise. In transnational organizations, when individuals are operating within foreign national cultures, what impact will value incongruence between individual and national cultures have on individual satisfaction and performance? Similarly, what impact will value incongruence have on diverse individuals operating in organizational cultures that espouse values different from their own? Is the relationship between national and organizational value congruity moderated by the mode of acculturation adopted by the organization and nation within which it resides?

Figure I demonstrates how different value systems, when examined together, have different levels of alignment. It serves to illustrate some of the possible alignment patterns between different organizational, national, and individual values. 


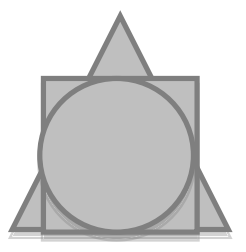

Scenario A

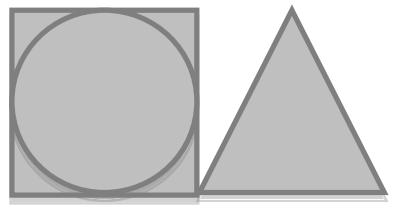

Scenario B

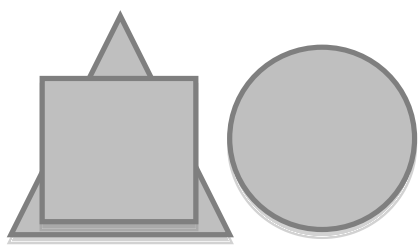

Scenario C

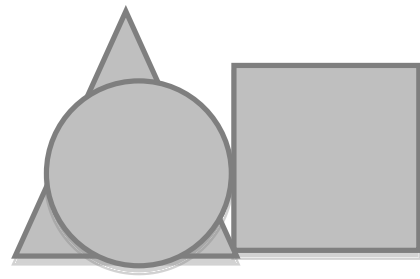

Scenario D
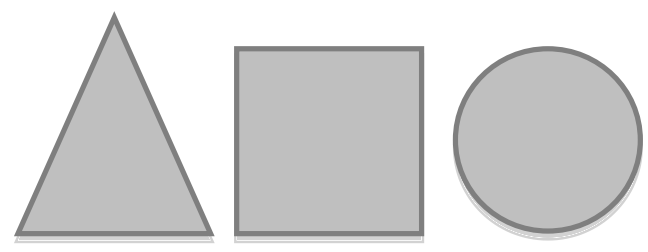

Scenario E

Triangle: Individual

Circle: Organization

Square: Nation

Figure I: The Interaction of Individual Values, Organizational Culture, and National Culture

Scenario A is illustrative of a situation where an individual's values are in alignment with organizational and national values. An example of this scenario could be a White male who is competitive and self-orientated in an organization that espouses and rewards individual achievement, in a nation that is characterized by high levels of individualism.

Scenario B is indicative of a situation where both the organizational and national cultures are in alignment but the individual's values are incongruent with those espoused by both the organization and nation. An example of this could be a self-oriented British male working for an organization that is highly team and group-orientated in a country, such as China, that is highly collectivistic.

Scenario C illustrates a situation where an organization's culture is incongruent with the national culture and individual's values (which are congruent). An example of this could be an American working for a Japaneseowned company in the U.S.

Scenario D is indicative of a situation where the individual's values are congruent with those espoused by the organization. However, the national culture is not in alignment with the values held by either the individual or the organization. An example of this may be an Australian working for a British firm in Kuwait.

Scenario E illuminates a situation in which none of the variables are in alignment. An example of this may be a Dutch woman who is relationally-oriented, working for an organization that is highly task-orientated in a country, such as China, that is highly group-oriented.

Although these scenarios highlight a few of the potential variations in value congruency patterns between individuals, organizations, and nations, the endless ways these patterns can vary, given within group variations, cannot be underestimated. Figure II serves to illustrate this point. 


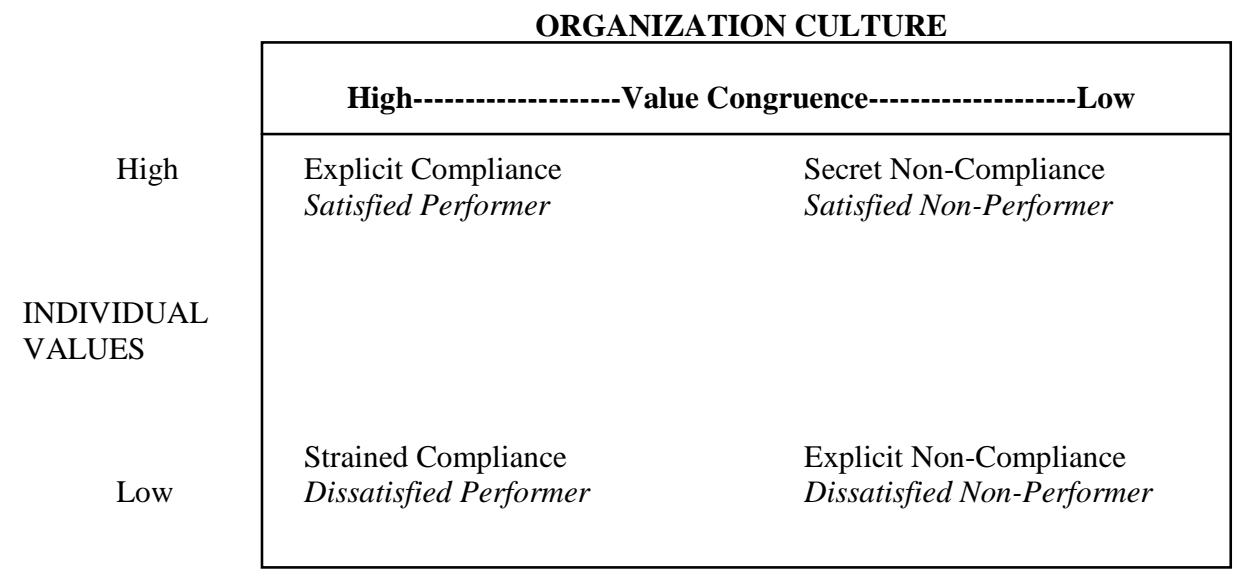

Figure II: Culture Congruence and Implications for Employee Satisfaction and Performance

Figure II provides a conceptual framework whereby value congruence and its impact on individual satisfaction and performance can be better understood. The framework suggests that the more congruent the organizations culture is with an individual employee's values, the more satisfied the employee will be and the better the employee will perform. Where individual value congruence is high and where the behavior executed by the employee is consistent with the employee's value system, but where the organization's culture and behavioral assumptions are not being adhered to, the employee is said to be secretly non-complying (a satisfied non-performer). Dissatisfied non-performers, on the other hand, may be performing as expected but feel dissatisfied with the organizational culture and the values it espouses. An example of this could be an individual who is performing to standard but is under an incredible amount of psychological stress as the tasks that they are required to perform do not concur with the values this person holds. An example of this could be a person working until 8pm in an organizational culture where working late is the norm but where they have children waiting at home for them. Arguably, dissatisfied performers could become explicit non-performers or secret non-performers and eventually leave the organization. Dissatisfied non-performers are employees that are clearly not performing (as required by the organization) and arguably will eventually either become dissatisfied performers or secret non-performers.

The issue of concern when examining the implications stemming from this framework, particularly when considering nontraditional workers, is whether the actual behavior of the individual is contrived, strained, or whether it comes naturally. The more the actual behavior is in sync with the person's values and the organizations culture, the less stress and more satisfaction is achieved. Furthermore, even where individuals and organizations experience an apparent "fit" and seem to be operating at optimal effectiveness, performance may be constrained by the national culture context in which they find themselves.

\section{IMPLICATIONS FOR DIVERSITY RESEARCH AND PRACTICE}

Empirical work in this area suggests that national culture must be considered along with organizational culture in order to fully understand the relation of an organization's culture to organizational functioning (Erez \& Early, 1993). Gelfand et al. (1996) argue that researchers need to pay more attention to the context in which individuals interact both at the organizational and national levels. One of the primary challenges for researchers attempting to link individual value differences, organizational culture, and national culture variables and measure the impact of their joint interaction is to find measures that are construct valid at each level. The typologies and dimensions presented in this paper provide a starting point for future research in this area. Attempts should be made to measure the moderating effect that acculturation has on culture fit and the mediating effect that culture fit has on individual satisfaction and organizational effectiveness. Measures of cultural relatedness and acculturative outcomes need to be reviewed, developed, and employed, and more research effort needs to be extended to better understand the impact that the interaction of diverse individual values, organizational cultures, and national cultures may have on individual and organizational outcomes. 
Research on diversity has revealed that diverse individuals or groups have lower levels of satisfaction and higher rates of turnover than more homogenous groups (Miliken \& Martins, 1996). Furthermore, studies suggest that organizations act systematically to drive out individuals who are different from the majority, unless this tendency toward homosocial reproduction is managed (Kanter, 1983). This inclination by organizations to drive out diversity is an exceptionally serious one that organizations that value diversity will need to develop mechanisms to contravene (Miliken \& Martins, 1996). Researchers should attempt to identify and isolate variables that serve to promote or inhibit this trend. They have the challenge of examining the interplay between values at the individual, organizational, and national level. In 1986, Adler et al. contended that less than one-fifth of all cross-cultural management research has focused on the interaction between different cultures. Tsui and Xi'an (2007) contend that while cross-cultural research has advanced significantly, there is still much fragmentation in comparative management research and a paucity of context-specific research.

Essentially, organizations that value diversity at all three levels and that implement programs to facilitate the adjustment and socialization of employees at the individual, organizational, and national culture level will be crucial for optimal individual and organizational performance. Xiao \& Tsui (2007) also emphasize that in order to integrate employees throughout the world into a globally cohesive organizational culture, while enhancing local responsiveness, transnational managers must understand cross-cultural interaction and the contingency effect that culture has on work effectiveness. Model I suggests that the key to successfully manage cultural diversity is to manage the interconnections between individual, organizational, and national levels of culture. Some of the implications of cultural incongruity for employees may include underperformance, nonperformance, dissatisfaction, demotion, or termination of employment. Some of the implications for organizations may include failure to achieve corporate goals, decreased productivity, loss of market share, or withdrawal from the market altogether. Recognition of the dynamic nature of culture and the interplay of individual, organizational, and national culture variables will provide a far better starting point for diversity management practices, particularly where cross-national borders are involved. Consistent with this, Adler \& Bartholomew (1992) argue that proactively creating a transnational organizational culture becomes more important than reactively assimilating into a dominant partner's national culture.

This paper emphasized that rather than merely focusing on the different values that individuals hold, more attention should be given -in both research and practice - to the impact the interaction these individual values, shared organizational values, and national culture values have on individual and organizational outcomes. This paper also proposed a conceptual framework that researchers and diversity managers can use to systematically consider the interplay of multiple levels of culture and its combined influence on workplace outcomes. A key issue this millennium will no longer merely be one of acknowledging the salience of cultural diversity or cross-cultural value differences, but also one of how best to manage the interaction of individual, organizational, and national culture variables such that more inclusive and collaborative work environments are fostered worldwide.

\section{AUTHOR INFORMATION}

Dr. Palthe is an Associate Professor of Management at Western Michigan University. She teaches MBA classes in managing change, leading people and organizations, international human resource management, and international management. Prior to earning her Ph.D. from Michigan State University, she was Senior Change Management Consultant for Accenture. She has publications in the International Journal of Intercultural Relations, Journal of Asia Business Studies, Journal of Education for Business, Competitiveness Review, Health Care Manager, Forum on Public Policy, California Management Review, Journal of Organizational Change Management, Consulting Psychology Journal, and book and chapter publications through Oxford University Press, SAGE, and SouthWestern College Publishing. E-mail: jennifer.palthe@wmich.edu

\section{REFERENCES}

1. Adler, N. (1983). Cross-cultural management research: The ostrich and the trend. Academy of Management Review, 8, 226-232.

2. Adler, N. J., Doktor, R., \& Redding, S. G. (1986). From the Atlantic to the Pacific century: Cross-cultural management reviewed. Journal of Management, 12(2), 295-318. 
3. Adler, N. J., \& Bartholomew, S. (1992). Academic and professional communities of discourse: Generating knowledge on transnational human resource management. Journal of International Business Studies, 23, 551-569.

4. Alderfer, C. P. (1982). Studying intergroup relations embedded in organizations. Administrative Science Quarterly, 27, 5-65.

5. Cox, T. H. (1993). Cultural differences. Cultural Diversity in Organizations: Theory, Research \& Practice (105-129). San Francisco: Berrett-Koeller.

6. Chatman, J. A. (1989). Improving interactional organizational research: A model of person-organization fit. Academy of Management Review, 14(3), 333-349.

7. Chatman, J. A. (1991). Matching people \& organizations: Selection and socialization in public accounting firms. Administrative Science Quarterly, 36, 459-484.

8. Deal, T. E., \& Kennedy, A. A. (1982). Corporate cultures: The rites \& rituals of corporate life. Reading, MA: Addison-Wesley.

9. Denison, D. R. (1990). Corporate culture \& organizational effectiveness. New York: John Wiley \& Sons.

10. Denison, D. R. (1996). What is the difference between organizational culture and organizational climate? A native's point of view on a decade of paradigm wars. Academy of Management Review, 21, 619-654.

11. Early, P. (1994). Self or group? Cultural effects of training on self efficacy and performance. Administrative Science Quarterly, 39, 88-117.

12. Erez, M., \& Early, C. (1993). Cultural self-representation theory. Culture, Self Identity, and Work. Oxford, U.K.: Oxford University Press.

13. Erez, M., \& Gati, E. (2004). A dynamic, multi-level model of culture: From the micro level of the individual to the macro level of a global culture. Applied Psychology: An International Review, 53(4), 583598.

14. Gelfand, M. J., Erez, M., \& Aycan, Z. (2007). Cross-cultural organizational behavior. Annual Review of Psychology, 58, 479-514.

15. Gelfand, M. J., Kuhn, K. M., \& Radhakrishnan, P. (1996). The effect of value differences on social interaction processes and job outcomes: Implications for managing diversity. In S. E. Jackson \& M. N. Ruderman (Eds.), Selected research on work team diversity (pp. 53-71). Washington, D.C.: American Psychological Association.

16. Hakanson, L. (1995). Learning through acquisitions. International Studies of Management and Organization, 25, 121-157.

17. Hofstede, G. (1980). Culture's consequences: International differences in work-related values. Beverly Hills, CA: Sage.

18. Hofstede, G., Neuijen, B., Ohayv, D. D., \& Sanders, G. (1990). Measuring organizational cultures: A qualitative and quantitative study across twenty cases. Administrative Science Quarterly, 35, 286-316.

19. House, R. J., Wright, N. S., \& Aditya, R. N. (1997). Cross-cultural research on organizational leadership: A critical analysis and a proposed theory. In M. Erez, \& P. C. Early (Eds.), New perspectives on international industrial/organizational psychology (pp.415-445). San Francisco, CA: The Lexington Press, 4.

20. House, R. J., Hanges, P. J., Ruiz-Quintanilla, S. A., Dorfman, P. W., Javidan, M., Dickson, M., Gupta, V., \& GLOBE. (1999). Cultural influences on leadership and organization: Project GLOBE. In W. H. Mobley, M. J. Gessner, \& V. Arnold (Eds.), Advances in global leadership (pp. 171-233). Stamford, CT: JAI Press.

21. Johnson, J. P., Lenartowicz, T., \& Apud, S. (2006). Cross-cultural competence in international business: Toward a definition and a model. Journal of International Business Studies, 37, 525-543.

22. Kanter, R. M. (1983). Men and women of the corporation. New York: Basic Books.

23. Kabanoff, B., Waldersee, R., \& Cohen, M. (1995). Espoused values and organizational change themes. Academy of Management Journal, 38(4), 1075-1104.

24. Kluckhohn, C. S., \& Strodbeck, F. L. (1961). Variations in values orientations. Evanston, IL: Row Peterson.

25. Kozlowski, S. W. J., \& Klein, K. J. (2000). A multilevel approach to theory and research in organizations: Contexual, temporal, and emergent processes. In K. Klein \& S. W. J. Kozlowski (Eds.), Multilevel theory, research, and methods in organizations (pp. 3-90). San Francisco: Jossey-Bass.

26. Miliken F. J., \& Martins, L. L. (1996). Searching for common threads: Understanding the multiple effects of diversity in organizational groups. Academy of Management Review, 21, 402-433. 
27. Nahavandi, A. M., \& Malekzadeh, A. R. (1988). Acculturation in mergers and acquisitions. Academy of Management Review, 13, 79-90.

28. Ostroff, C., \& Rothausen, T. J. (1997). The moderating effect of tenure in person-environment fit: A field study in educational organizations. Journal of Occupational \& Organizational Psychology, 70, 173-188.

29. Peters, T. J., \& Waterman, R. H. (1982). In search of excellence. New York: Harper and Row.

30. Sathe, V. (1985). Culture and related corporate realities. Illinois: Harvard Business School.

31. Schein, E. H. (1985). Organizational culture and leadership. San Francisco: Jossey-Bass.

32. Schwartz, S. H. (1990). Individualism-collectivism: Critique and proposed refinements. Journal of CrossCultural Psychology, 21, 139-157.

33. Schwartz, S. H. (1994). Cultural dimensions of values: Towards an understanding of national differences. In U. Kim \& G. Yoon, Individualism and Collectivism: Theoretical and Methodological Issues (pp. 85119). Newbury Park, CA: Sage.

34. Stahl, G. K., Maznevski, M. L., Voigt, A., \& Jonsen, K. (2010). Unraveling the effects of cultural diversity in teams: A meta-analysis of research on multicultural work groups. Journal of International Business Studies, 41, 690-709.

35. Triandis, H. C. (1995). The importance of contexts in studies of diversity. In S. E. Jackson \& M. N. Ruderman (Eds.), Diversity in work teams: Research paradigms for a changing workplace (pp. 225-233). Washington D.C.: American Psychological Association.

36. Triandis, H. C., Kurowski, L., \& Gelfand, M. (1994). Workplace diversity. In H. C. Triandis, M. Dunnette, \& L. M. Hough, Handbook of industrial/organizational psychology (4, pp. 776-815).

37. Tsui, A. S. (2007). From homogenization to pluralism: International management research in the Academy and beyond. Academy of Management Journal, 50, 1353-1364.

38. Tsui, A. S., Xin, K. R., \& Egan, T. D. (1995). Relational demography: The missing link in vertical dyad linkage. In S. E. Jackson \& M. N. Ruderman (Eds.), Diversity in work teams: Research paradigms for a changing workplace. Washington, D.C.: American Psychological Association.

39. Xiao, Z. X., \& Tsui, A. S. (2007). Where brokers may not work: The culture contingency of social capital. Administrative Science Quarterly, 51, 1-31. 


\section{NOTES}

